\title{
First record of Japanese Mystery Snail Cipangopaludina japonica (von Martens, 1861) in Texas
}

\author{
Bianca J. Perez ${ }^{1}$, Averi Harp Segrest ${ }^{1}$, Sofia R. Campos ${ }^{1}$, Russell L. Minton ${ }^{2}$ and Romi L. Burks ${ }^{1 *}$ \\ 1 Southwestern University, Department of Biology, 1001 East University Avenue, Georgetown, TX, USA 78626 \\ 2 University of Houston Clear Lake, College of Science and Computer Engineering, 2700 Bay Area Blvd MC39, Houston, TX, USA 77058 \\ * Corresponding author. E-mail: burksr@southwestern.edu
}

\begin{abstract}
Two Cipangopaludina snails were discovered in Harris County, Texas, USA, during routine fieldwork in October 2015. Dissection yielded one male and one female containing 52 offspring in her brood pouch. Phylogenetic analysis of the cytochrome $c$ oxidase subunit I (COI) gene confirmed both individuals to be Cipangopaludina japonica (von Martens, 1861). This is the first distribution record of $C$. japonica in Texas. Non-native invasive snails, such as $C$. japonica, compete with native species and may serve as reservoirs for parasites, prompting the need for increased diligence in monitoring public waterways.
\end{abstract}

Key words: aquarium trade; Bellamya; Gastropoda; globalization; invasive; non-native

The Japanese Mystery Snail, Cipangopaludina japonica (von Martens, 1861) (Gastropoda: Viviparidae), is a freshwater snail native to eastern Asia (Clench and Fuller 1965; Jokinen 1992) that was first recorded in the United States in the late nineteenth century in California (Wood 1892; Hannibal 1911). The United States Geological Survey's Nonindigenous Aquatic Species Database (USGS 2016; Appendix, Table A1) only contains records of $C$. japonica populations for 15 states, but several other state natural resource agencies (DNRs) report populations of $C$. japonica (Figure 1 ) that do not appear in the national database (Appendix, Table A2). Cipangopaludina japonica is closely related to, and often confused with or misidentified as, the more widespread and invasive Chinese Mystery Snail, C. chinensis (Gray, 1834), another species that the Asian food markets also brought into the United States in the early 1890s (Jokinen 1982). Cipangopaludina chinensis occurs extensively across the United States with the highest densities found in the Great Lakes and the northeastern United States (Figure 2; Appendix, Table A1).

Accidental or deliberate introductions (Kipp et al.
2016) of these mystery snails into new habitats pose ecological concerns as both species have the ability to reach high population densities (Chaine et al. 2012), compete with native species (Solomon et al. 2010) and alter aquatic ecosystems (Johnson et al. 2009). Like many other freshwater snails, these viviparids also act as intermediate hosts for parasites that pose serious health risks, including the nematode Angiostrongylus cantonensis (Lin and Chen 1980) and Echinostoma cinetorchis, a species of human intestinal fluke (Park et al. 1997; Chung and Jung 1999). The combined threats mystery snails pose to human and environmental health coupled with their invasive history (Wolfert and Hiltunen 1968; Soes et al. 2011) often land both $C$. chinensis and C. japonica on invasive species watch lists (Kipp et al. 2016).

Both species are also frequently placed in the genus Bellamya versus Cipangopaludina based on morphological features (Smith 2000; Bury et al. 2007), but debate exists on whether this represents a true synonymy (Van Bocxlaer and Strong 2016). The Integrated Taxonomic Information System does not recognize the nomenclature of Bellamya (Havel et al. 2014), but several recent studies chose to use this name for the genus over Cipangopaludina (Smith 2000; Solomon et al. 2010; Soes et al. 2011). Consequently, the taxonomy of both $C$. chinensis and $C$. japonica remains unclear as many scientific names are improperly synonymized or used inconsistently (Global Invasive Species Database 2016). Based on an extensive comparative study of internal morphology, Van Bocxlaer and Strong (2016) argued for the validity of the genus Cipangopaludina to better reflect evolutionary relationships and further called for rigorous molecular studies to resolve the relationships of $C$. chinensis, $C$. malleata and $C$. japonica. Given the similarity of $C$. japonica to $C$. chinensis, along with the comparative limited information on $C$. japonica, we provide background for both species.

Cipangopaludina japonica and C. chinensis exhibit 


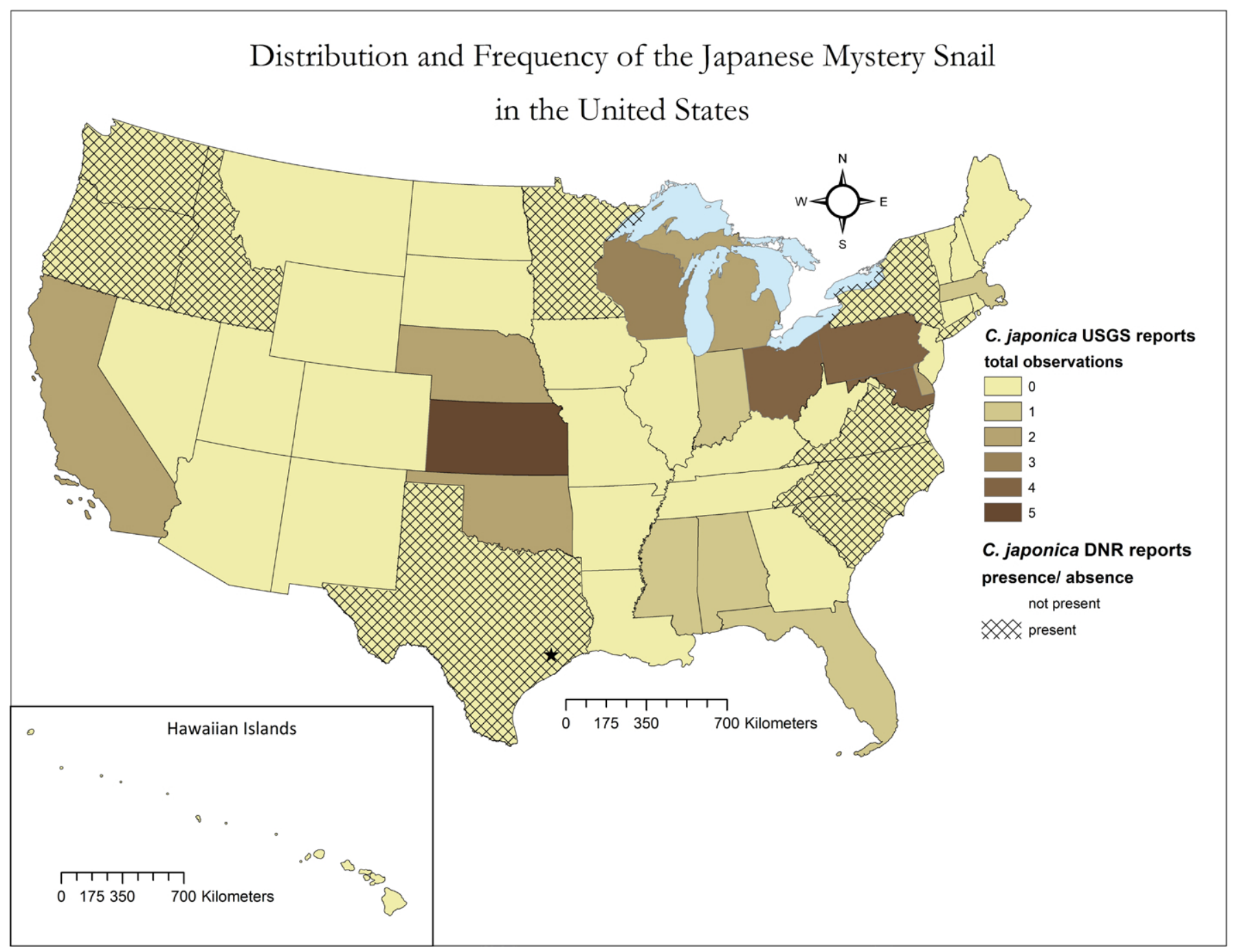

Figure 1. Distribution of Cipangopaludina japonica collections reported in the United States (USGS 2016). Records of C. japonica exist for fifteen states on the USGS Nonindigenous Aquatic Species Database (AL, CA, DE, FL, IN, KS, MA, MD, MI, MS, NE, OH, OK, PA, WI) although several other state departments of natural resources (ID, MN, NY, NC, OR, PA, SC, VA, WA, WI) include information about introductions on their websites (hatched states). A black star represents our collection of $C$. japonica in Harris County, Texas. The closest occurrence of $C$. japonica to our present collection occurs approximately 518 km away in Lake Ardmore, OK (USGS 2016).

similar life histories and occupy equivalent ecological niches (Jokinen 1982). Both taxa commonly occur in lentic ponds and lakes that have sandy to muddy substrates. Both species feed non-specifically on benthic organic matter (Jokinen 1982). In a study that altered water levels in rice paddy soils, Kurihara and Kadowaki (1988) found that submerged soils provided a suitable habitat in which $C$. japonica consumed primarily detritus and successfully reproduced. With a generalist diet, long life spans and high fecundity, populations of mystery snails may grow quickly (Stephen et al. 2013).

Based on estimates, female mystery snails may live for approximately five years, with a shorter life expectancy for males of three to four years (Jokinen 1982; Van Bocxlaer and Strong 2016). After their first year, females become reproductively active and release live offspring. Reproduction occurs continuously throughout spring to early summer when females carry embryos that they later release June through October (Jokinen 1982). Mature females release an average of 25 offspring per year and 130 offspring during their lifetime, although as many as 133 offspring have been documented in a single individual of C. chinensis (Stephen et al. 2013) and 178 offspring from one $C$. japonica specimen (Van Bocxlaer and Strong 2016). Offspring measure approximately 5 $\mathrm{mm}$ in size at birth. Juveniles can reach $35 \mathrm{~mm}$ in size after their first year and adults can measure up to 65 mm in size (Clench and Fuller 1965; Jokinen 1982).

Based on morphometric analysis, Cipangopaludina japonica lacks external morphological characters that provide consistent reliable field identifications of sex (Van Bocxlaer and Strong 2016). Field identification of $C$. japonica and $C$. chinensis may also prove difficult, as Smith (2000) suggested that $C$. japonica differs the most from $C$. chinensis with respect to the embryonic shell. Shells with more acute spires and finer carinae 


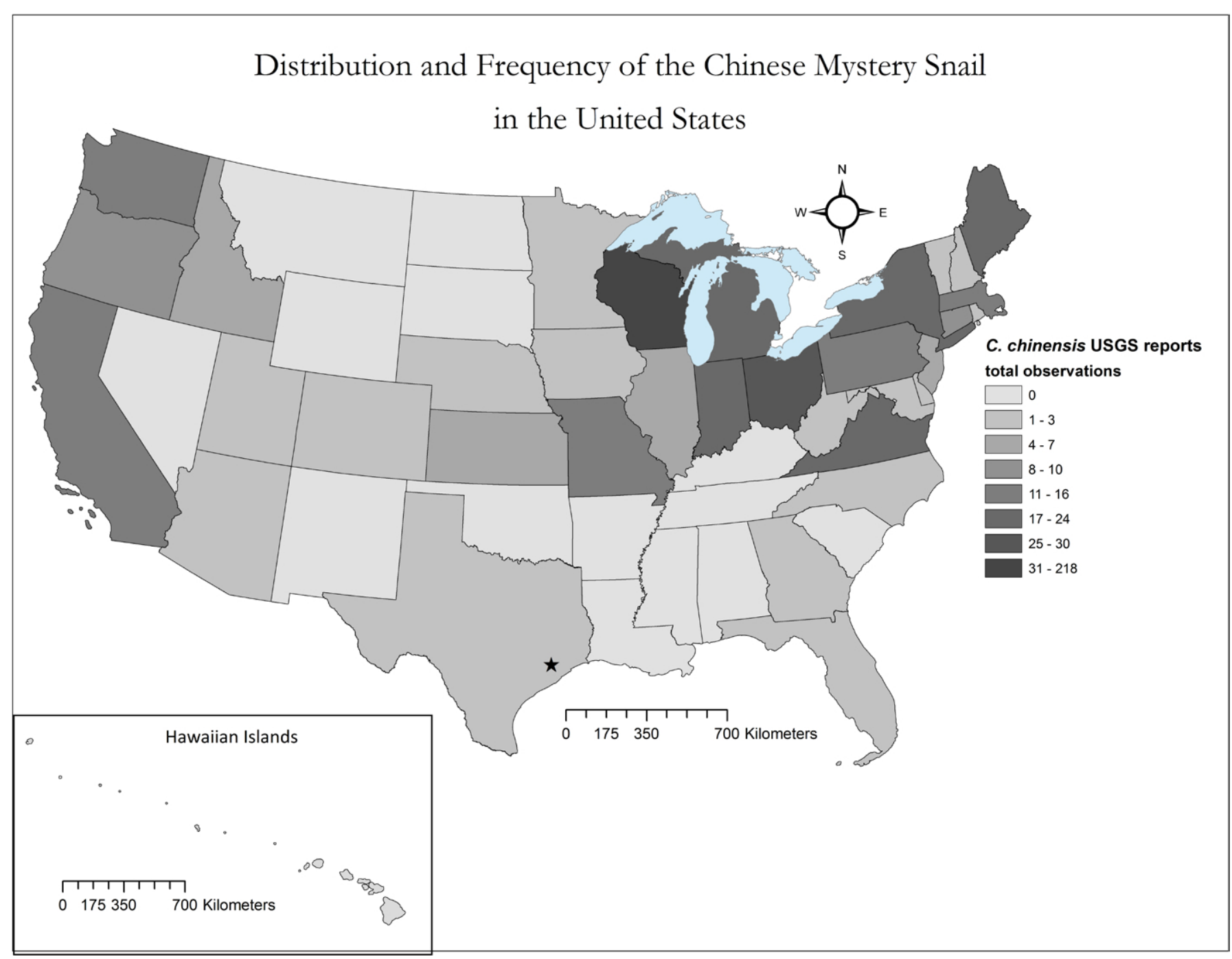

Figure 2. Distribution map of Cipangopaludina chinensis collections reported in the United States (USGS 2016). Cipangopaludina chinensis occurs extensively across the United States with the highest densities found in the Great Lakes and the northeastern United States. A black star represents our collection of C. japonica in Harris County, Texas.

suggest $C$. japonica over $C$. chinensis (Clench and Fuller 1965; Jokinen 1982; Park et al. 1997; Smith 2000). However, those traits only have utility within a small size range (35-45 $\mathrm{mm}$ ) in both species (Smith 2000). Smith (2000) also noted that the vas deferens in $C$. japonica is branched compared to $C$. chinensis, and that juvenile $C$. chinensis show depressed embryonic whorls. Although shell morphology may fail to distinguish the two Cipangopaludina species, molecular data consistently separates them. For example, Hirano et al. (2015) employed two mitochondrial genes, cytochrome $c$ oxidase subunit I (COI) and 16s rRNA to show clear distinctions between $C$. japonica and $C$. chinensis. In this paper, we provide morphological information along with genetic confirmation of $C$. japonica from a population in Harris County, Texas.

Using field nets, two individual mystery snails (Figures 3 and 4) were discovered in October 2015 while collecting the invasive gastropod Pomacea maculata Perry, 1810 (Texas Parks and Wildlife Department permit no.
RES0301.74) in the Missouri City Community Pond in Harris County, Texas $\left(29^{\circ} 34^{\prime} 04.4^{\prime \prime} \mathrm{N}, 095^{\circ} 31^{\prime} 36.2^{\prime \prime} \mathrm{W}\right)$. We collected both mystery snails for subsequent

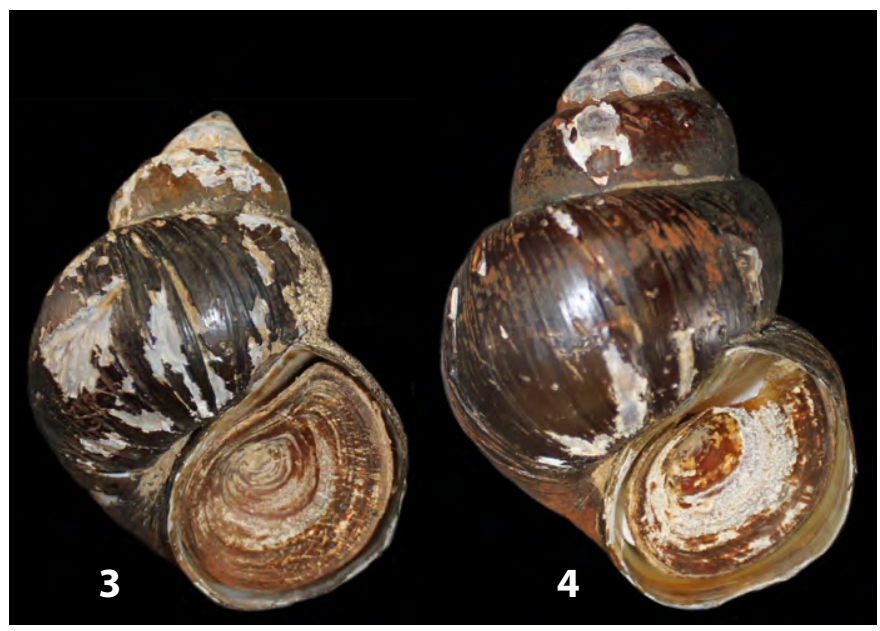

Figures 3 and 4. Cipangopaludina japonica collected at the Missouri City Community Pond in Harris County, Texas. 3: Male $(53.1 \mathrm{~mm}$ length, 38.0 $\mathrm{mm}$ width). 4: Female (62.8 $\mathrm{mm}$ length, $43.9 \mathrm{~mm}$ width). 
identification and initially froze them at $-20^{\circ} \mathrm{C}$ before dissection to determine sex and whether the female carried any offspring. We preserved foot tissue and offspring found in the brood pouch in $70 \% \mathrm{ETOH}$. The shells and offspring are stored as voucher material at the North Carolina Museum of Natural Sciences in Raleigh, North Carolina (NCSM 101740 for the male and NCSM 101741 for the female and brood).

To confirm our morphological identification of the two snails, we sequenced the mitochondrial COI gene to ascertain species identity (Hebert et al. 2003). We extracted total genomic DNA from a small piece $\left(\sim 1 \mathrm{~mm}^{2}\right)$ of unpigmented foot tissue using a NucleoSpin ${ }^{\circledR}$ extraction kit (Macherey-Nagel, Pennsylvania, USA). Following the conditions used in Hayes et al. (2009), we amplified a $709 \mathrm{bp}$ fragment of the COI gene by polymerase chain reaction $(\mathrm{PCR})$ using the standard invertebrate primer pair LCO1490 (5'-GGTCAACAAATCATAAAGATATTGG) and HCO2198 (5'-TAAACTTCAGGGTGACCAAAAAATCA) (Folmer et al. 1994). The Institute for Cellular and Molecular Biology at the University of Texas at Austin performed Sanger sequencing in both directions using an ABI BigDye Terminator v.3.1 Cycle Sequencing Kit (Perkin-Elmer Applied Biosystems, Inc.) on an ABI 3730 XL capillary sequencer following the manufacturer's instructions.

Using MUSCLE ver. 3.6 (Edgar 2004), we aligned our sequences with Genbank sequences from 47 other Cipangopaludina spp. (Appendix, Table A3) and three Viviparus spp. as outgroups ( $n=51$ total sequences). We used jModelTest ver. 2.1.7 (Darriba et al. 2012) to determine the best fit model based on Akaike Information Criterion (AIC) and estimated phylogenetic relationships under maximum likelihood using the $\operatorname{TrN}+\mathrm{G}$ model in PhyML ver. 3.0 (Guindon et al. 2010). Node support was estimated with 1000 bootstrap replicates (Felsenstein 1985). We edited and visualized the consensus tree in FigTree 1.3.1 (Rambaut 2009).

We identified the two snails as a species of nonnative Cipangopaludina based on shell shape and size. All native viviparids in the U.S. are smaller and possess different shell forms than $C$. japonica and C. chinensis (Burch 1982). Based on the acute spires and more ovate apertures (Lu et al. 2014; Hirano et al. 2015), we assigned both specimens putatively to $C$. japonica. Dissection revealed one male (Figure 3 ) and one female (Figure 4) with 52 offspring in her brood pouch. Offspring showed slightly depressed embryonic whorls but not enough to be indicative of $C$. chinensis. The female shell $(62.8 \mathrm{~mm}$ length and $43.9 \mathrm{~mm}$ width) was larger than the male (53.1 mm length and $38.0 \mathrm{~mm}$ width) and both were larger and had thinner shells than most native viviparids (Burch 1982).

For genetic analysis, we edited and assembled our COI sequences in Geneious 7.1 (Biomatters Ltd.). Sequences from the male and female were $658 \mathrm{bp}$ in length and
100\% identical (GenBank accession KX259343). Phylogenetic analysis yielded a single tree (log likelihood $=-2106.8749$, model $=\operatorname{TrN}+\mathrm{G}$ ) clustering both snails in a clade with other $C$. japonica specimens (Figure 5), confirming our field identification. The $C$. japonica clade was well supported (> 50\%) and clearly separate from specimens of $C$. chinensis.

Our collection of two individual Cipangopaludina japonica represents the first record of this species in Texas (USGS 2016). To our knowledge, this work presents the first published sequence of the COI gene for $C$. japonica obtained from a United States population.

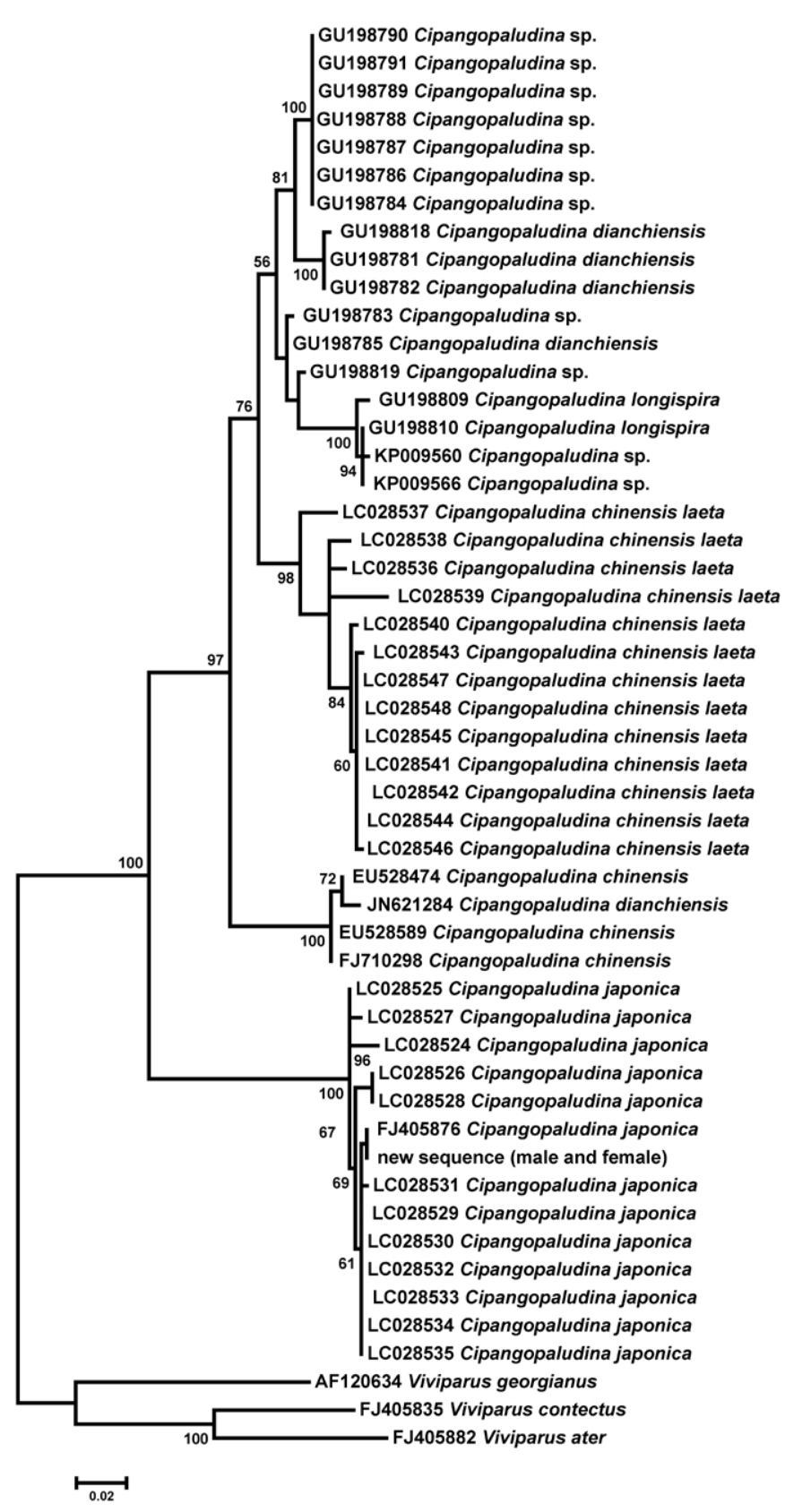

Figure 5. Maximum likelihood phylogeny (-log likelihood $=-2106.8749$, model $=\operatorname{TrN}+\mathrm{G}$ ) including 47 Cipangopaludina spp., three Viviparus outgroups, and our new sequence $(n=51)$. Nodes with greater than $50 \%$ bootstrap support are indicated by node values. 
The USGS Nonindigenous Aquatic Species Database lists collections in 15 states but our state-by-state examination of DNR websites also discovered a number of states that reported introductions of $C$. japonica not present in the national database. Lack of centralized reporting raises questions as to the closest source populations for introductions. Cipangopaludina chinensis introductions appear better documented, including a widespread distribution within the Saint John River in New Brunswick, Canada (McAlpine et al. 2016).

The closest known collection of $C$. japonica to our field site occurs approximately $518 \mathrm{~km}$ away in Lake Ardmore, Oklahoma (USGS 2016). Overall, our discovery of large, reproducing adults in a degraded urban pond raises serious ecological concerns about the potential of $C$. japonica to survive overland exposure (Havel et al. 2014), and even perhaps overwinter. Wide environmental tolerances would enable the species to establish new populations more easily, particularly in areas already invaded by other, non-native invasive mollusks such as P. maculata (Karatayev et al. 2009). Non-native invasive snails, such as $C$. japonica, compete with native species (Johnson et al. 2009) and may serve as reservoirs for parasites (Lin and Chen 1980; Chung and Jung 1999), prompting the need for increased diligence in monitoring public waterways.

Although we identified our specimens as $C$. japonica, the majority of published research includes individuals morphologically identified as $C$. chinensis. We therefore used these studies for comparison purposes when addressing issues of spread and ecological impact. In terms of their potential to spread, both $C$. japonica and C. chinensis can likely survive long periods of overland exposure. Both $C$. japonica and $C$. chinensis possess an operculum that partially functions in preventing water loss. In one experiment, large $C$. chinensis juveniles (greater than $25 \mathrm{~mm}$ ) survived up to four weeks of air exposure while smaller juveniles (less than $10 \mathrm{~mm}$ ) showed greater sensitivity to air exposure and low humidity (Havel 2011). In another experiment, adult C. chinensis survived an average of 44.6 days ( \pm 4.9 as $1 \mathrm{SD}$ ) when left vulnerable to air exposure (Havel et al. 2014). Due to anatomical similarities between the two species, $C$. japonica can also likely survive long periods of overland exposure. Quantifying the ability of non-native freshwater snails to survive air exposure and overland transport provides direct insight into their ability to colonize new bodies of water and impact native species.

In terms of ecological impacts, initial evidence from one study suggests that $C$. chinensis negatively affects native species. In a mesocosm experiment, $C$. chinensis decreased sediment periphyton, significantly increased the ratio of $\mathrm{N}: \mathrm{P}$ in the water column, and negatively influenced the abundance of the gastropod Lymnaea stagnalis (Johnson et al. 2009). Given their morphological similarities and shared ecological roles, we might expect similar survival abilities and ecological impacts for C. japonica. Kurihara and Kadowaki (1988) reported that $C$. japonica grazed heavily on sedimentassociated detritus, likely altering nutrient cycles. Furthermore, populations of $C$. chinensis occur at high densities and establish sustaining populations rapidly, which may also occur for $C$. japonica. One of the few population estimates for $C$. chinensis calculated 52,280 snails per $0.1 \mathrm{~km}^{2}$ and up to 253,570 snails in a Nebraska reservoir (Chaine et al. 2012). In Long Island, NY, a population of $C$. chinensis increased from an estimated 150 individuals to an estimated 950 individuals within a two-year time period (McCann 2014). These high population levels could also be reached by $C$. japonica where anecdotal evidence exists in which fishermen have reported catching up to two tons of $C$. japonica from a single seine haul (Wolfert and Hiltunen 1968).

Survival probabilities of $C$. chinensis depend on size, with snails over $35 \mathrm{~mm}$ in length having almost a $100 \%$ probability of survival based on mark-recapture studies (McCann 2014). Higher survival rates for larger individuals likely apply to $C$. japonica and fecundity in this species increases predictably with female body size (Van Bocxlaer and Strong 2016). Distribution of mystery snails across northern and southern latitudes in the United States suggests the ability of this group to tolerate a wide range of temperatures (Karatayev et al. 2009; Solomon et al. 2010). Further investigation of the community pond area and connected waterways in Texas could provide insight into the distribution of $C$. japonica as well as the source of introduction (Karatayev et al. 2009).

Besides the predictable negative effects on native species and ecosystems (Solomon et al. 2010; Soes et al. 2011), non-native viviparids pose genuine disease risks. If consumed, Cipanopaludina spp. may transfer human intestinal fluke, Echinostoma cinetorchis (Jokinen 1982; Chung and Jung 1999) or serve as a vector for angiostrongyliasis (Lin and Chen 1980). Overall, the discovery of $C$. japonica in Texas highlights the ability of mystery snails to survive in urban waterways and indicates the likelihood that populations may spread successfully across the southern United States. Furthermore, our study affirms the need for genetic identification of species introductions to reduce taxonomic confusion and supports the need for improved monitoring programs coupled with a comprehensive centralized database to better track non-native invasive aquatic species.

\section{ACKNOWLEDGEMENTS}

A grant from the Keck Foundation for molecular biology research at Southwestern University provided the funding for this project. The Howard Hughes Medical Institute (HHMI) Inquiry Based Initiative at 
Southwestern University provided financial support for the initial collection. Anwar Sounny-Slitine helped with creating the distribution maps. Elizabeth Williams and Adrian Medellin provided on-site logistical support in the field.

\section{LITERATURE CITED}

Burch, J.B. 1982. North American freshwater snails. Identification keys, generic synonymy, supplemental notes, glossary, references, index. Walkerana 1(4): 217-365.

Bury, J.A., B.E. Sietman and B.N. Karns. 2007. Distribution of the non-native viviparid snails, Bellamya chinensis and Viviparus georgianus, in Minnesota and the first record of Bellayma japonica from Wisconsin. Journal of Freshwater Ecology 22(4): 697-703. doi: 10.1080/02705060.2007.9664830

Chaine, N.M., C.R. Allen, K.A. Fricke, D.M. Haak, M.L. Hellman, R.A. Kill, K.T. Nemec, K.L. Pope, N.A. Smeenk, B.J. Stephen, D.R. Uden, K.M. Unstad and A.E. VanderHam. 2012. Population estimate of Chinese mystery snail (Bellamya chinensis) in a Nebraska reservoir. BioInvasions Records 1(4): 283-287. doi: 10.3391/bir.2012.1.4.07

Clench, W.J. and S. Fuller. 1965. The genus Viviparus (Viviparidae) in North America. Occasional Papers on Mollusks 2(32): 385-412.

Chung, P.R. and Y. Jung. 1999. Cipangopaludina chinensis malleata (Gastropoda: Viviparidae): A new second molluscan intermediate host of a human intestinal fluke Echinostoma cinetorchis (Trematoda: Echinostomatidae) in Korea. The Journal of Parasitology 85(5): 963-964.

Darriba, D., G.L. Taboada, R. Doallo and D. Posada. 2012. jModelTest 2: more models, new heuristics and parallel computing. Nature Methods 9: 772-772. doi: 10.1038/nmeth.2109

Du, L.N., J.X. Yang, T. Von Rintelen, X.Y. Chen and D. Aldridge. 2013. Molecular phylogenetic evidence that the Chinese viviparid genus Margarya (Gastropoda: Viviparidae) is polyphyletic. Chinese Science Bulletin 58(18): 2154-2162. doi: 10.1007/ s11434-012-5632-y

Edgar, R.C. 2004. MUSCLE: multiple sequence alignment with high accuracy and high throughput. Nucleic Acids Research 32(5): 1792-1797. doi: 10.1093/nar/gkh340

Felsenstein, J. 1985. Confidence limits on phylogenies: an approach using the bootstrap. Evolution 39(4): 783-791. doi: $10.2307 / 2408678$

Folmer, O., M. Black, W. Hoeh, R. Lutz and R. Vrijenhoek. 1994. DNA primers for amplification of mitochondrial cytochrome $c$ oxidase subunit I from diverse metazoan invertebrates. Molecular Marine Biology and Biotechnology 3(5): 294-299. http://www. mbari.org/wp-content/uploads/2016/01/Folmer_94MMBB.pdf

Giribet, G. and W.C. Wheeler. 2002. On bivalve phylogeny: a highlevel analysis of the Bivalvia (Mollusca) based on combined morphology and DNA sequence data. Invertebrate Biology 121(4): 271-324. doi: 10.1111/j.1744-7410.2002.tb00132.x

Global Invasive Species Database. [2016]. Species profile: Cipangopaludina chinensis. Accessed at http://www.iucngisd.org/gisd/ speciesname/Cipangopaludina+chinensis, 16 August 2016.

Gray, J.E. 1834. [Various undescribed shells]. Proceedings of the Zoological Society of London 1834: 57-58. http://biodiversity library.org/page/30568362

Guindon, S., J.F. Dufayard, V. Lefort, M. Asinimova, W. Horkijk and O. Gascuel. 2010. New algorithms and methods to estimate maximum-likelihood phylogenies: assessing the performance of PhyML 3.0. Systematic Biology 59(3): 307-321. doi: 10.1093/ sysbio/syq010

Hannibal, H. 1911. Further notes on Asiatic viviparas in California. The Nautilus 25(3): 31-32. http://biodiversitylibrary.org/ page/26379826
Havel, J.E. 2011. Survival of the exotic Chinese mystery snail (Cipangopaludina chinensis malleata) during air exposure and implications for overland dispersal by boats. Hydrobiologia 668(1): 195-202. doi: 10.1007/s10750-010-0566-3

Havel, J.E., L.A. Bruckerhoff, M.A. Funkhouser and A.R. Gemberling. 2014. Resistance to desiccation in aquatic invasive snails and implications for their overland dispersal. Hydrobiologia 741(1): 89-100. doi: 10.1007/s10750-014-1839-z

Hayes, K.A., R.C. Joshi, S.C. Thiengo and R.H. Cowie. 2008. Out of South America: multiple origins of non-native apple snails in Asia. Diversity and Distributions 14(4): 701-712. doi: 10.1111/j.1472-4642.2008.00483.x

Hayes, K.A., R.H. Cowie and S.C. Thiengo. 2009. A global phylogeny of apple snails: Gondwanan origin, generic relationships, and the influence of outgroup choice (Caenogastropoda: Ampullariidae). Biological Journal of the Linnean Society 98(1): 61-76. doi: 10.1111/j.1095-8312.2009.01246.x

Hebert, P.D., A. Cywinska, S.L. Ball and J.R. deWaard. 2003. Biological identifications through DNA barcodes. The Royal Society Biological Sciences 270(1512): 313-321. doi: 10.1098/ rspb.2002.2218

Hirano, T., T. Saito and S. Chiba. 2015. Phylogeny of freshwater viviparid snails in Japan. Journal of Molluscan Studies 81(4): 435-441. doi: 10.1093/mollus/eyv019

Jiao, M., S. Ouyang, and X. Wu. [Unpublished]. DNA barcoding and phylogenetic analysis of Bellamya (Gastropoda: Viviparidae) based on mitochondrial COI and 16S rRNA genes.

Johnson, P.T., J. Olden, C. Solomon and M. Vander Zanden. 2009. Interactions among invaders: community and ecosystem effects of multiple invasive species in an experimental aquatic system. Oecologia 159(1): 161-170. doi: 10.1007/s00442-008-1176-x

Jokinen, E.H. 1982. Cipangopaludina chinensis (Gastropoda, Viviparidae) in North America, review and update. The Nautilus 96(3): 89-95.

Jokinen, E.H. 1992. The freshwater snails (Mollusca: Gastropoda) of New York State. New York State Museum Bulletin 482: 1-112.

Karatayev, A.Y., L. Burlakova, V. Karatayev and D. Padilla. 2009. Introduction, distribution, spread, and impacts of exotic freshwater gastropods in Texas. Hydrobiologia 619(1): 181-194. doi: 10.1007/s10750-008-9639-y

Kipp, R.M., A.J. Benson, J. Larson and A. Fusaro. 2016. Cipangopaludina japonica. USGS Nonindigenous Aquatic Species Database, Gainesville, FL. Accessed at http://nas.er.usgs.gov/ queries/factsheet.aspx?SpeciesID $=1046$, revision date: 6 May 2012.

Kurihara, Y., and K.-I. Kadowaki. 1988. Effect of different ecological conditions on the mud snail (Cipangopaludina japonica) in submerged paddy soil. Biology and Fertility of Soils 6(4): 292297. doi: $10.1007 /$ BF00261015

Lin, C.Y., and S.N. Chen. 1980. Epidemiologic studies of angiostrongyliasis in northern Taiwan. Medical Journal of Osaka University 31(1-2): 7-12.

Lu, H.F., L.N. Du, Z.Q. Li, X.Y. Chen, and J.X. Yang. 2014. Morphological analysis of the Chinese Cipangopaludina check for this species in other resources species (Gastropoda; Caenogastropoda: Viviparidae). Zoological Research 35(6): 510-527. doi: 10.13918/j.issn.2095-8137.2014.6.510

Martens, E. von. 1861. Die japanesischen Binnenschnecken im Leidner Museum. Malakozoologische Blätter 7: 32-61. http:// biodiversitylibrary.org/page/15919572

McAlpine, D.F., D.A.W. Lepitzki, F.W. Schueler, F.J.T. McAlpine, A. Hebda, R.G. Forsyth, A. Nicolai, J.E. Maunder and R.G. Noseworthy. 2016. Occurrence of the Chinese Mystery Snail, Cipangopaludina chinensis (Gray, 1834) (Mollusca: Viviparidae) in the Saint John River system, New Brunswick, with review of status in Atlantic Canada. Bioinvasion Records 5(3): 149-154. doi: 10.3391/bir.2016.5.3.05 
McCann, M.J. 2014. Population dynamics of the non-native freshwater gastropod, Cipangopaludina chinensis (Viviparidae): a capture-mark-recapture study. Hydrobiologia 730(1): 17-27. doi: 10.1007/s10750-014-1819-3

Park, G.M., K.H. Jeong, Y. Jung and P.R. Chung. 1997. A comparative study of two species of Viviparidae (Mollusca: Prosobranchia): Cipangopaludina chinensis malleata and C. japonica in Korea. Korean Journal of Malacology 13(1): 9-19.

Rambaut, A. 2009. FigTree v1.3.1 2006-2009. Accessed at http:// tree.bio.ed.ac.uk/software/figtree, 19 August 2016.

Sengupta, M.E., T.K. Kristensen, H. Madsen and A. Jorgensen. 2009. Molecular phylogenetic investigations of the Viviparidae (Gastropoda: Caenogastropoda) in the lakes of the Rift Valley area of Africa. Molecular Phylogenetics and Evolution 52(3): 797-805. doi: 10.1016/j.ympev.2009.05.007

Smith, D.G. 2000. Notes on the taxonomy of introduced Bellamya (Gastropoda: Viviparidae) species in northeastern North America. The Nautilus 114(2): 31-37. http://biodiversitylibrary. org/page/8271691

Soes, D.M, G.D. Majoor and S.M.A. Keulen. 2011. Bellamya chinensis (Gray, 1834) (Gastropoda: Viviparidae), a new alien snail species for the European fauna. Aquatic Invasions 6(1): 97-102. doi: 10.3391/ai.2011.6.1.12

Solomon, C.T., J. Olden, P. Johnson, R. Dillon Jr. and M.J. Vander Zanden. 2010. Distribution and community-level effects of the Chinese mystery snail (Bellamya chinensis) in northern Wisconsin lakes. Biological Invasions 12(6): 1591-1605. doi: 10.1007/s10530-009-9572-7

Stephen, B.J., C.R. Allen, N.M. Chaine, K.A. Fricke, D.M. Haak, M.L. Hellman, R.A. Kill, K.T. Nemec, K.L. Pope, N.A. Smeenk, D.R. Uden, K.M. Unsted, A.E. Vanderham and A. Wong. 2013. Fecundity of the Chinese mystery snail in a Nebraska reservoir. Journal of Freshwater Ecology 28(3): 439-444. doi: 10.1080/02705060.2013.769127

Tian, M., B. Fan, W.L. Wang, and Y.X. Chen. [Unpublished]. Studies on the molecular phylogenetic relationships of Margarya melanoides (Gastropoda: Viviparidae).

USGS [United States Geological Survey]. 2016. Nonindigenous Aquatic Species Database, Gainesville, FL. Accessed at http:// nas.er.usgs.gov, 23 August 2016.

Van Bocxlaer, B. and E.E. Strong. 2016. Anatomy, functional morphology, evolutionary ecology and systematics of the invasive gastropod Cipangopaludina japonica (Viviparidae: Bellamyinae). Contributions to Zoology 85(2): 235-236. http://repository. naturalis.nl/document/637623

Wolfert, D.R. and J.K. Hiltunen. 1968. Distribution and abundance of the Japanese snail, Viviparus japonicus, and associated macrobenthos in Sandusky Bay, Ohio. Ohio Journal of Science 68(1): 32-40. http://hdl.handle.net/1811/5359

Wood, W.M. 1892. Paludina japonica Mart. for sale in the San Francisco Chinese markets. The Nautilus 5(10): 114-115. http:// biodiversitylibrary.org/page/12566071

Author contributions: RM and RB designed the study; BP and AS collected the specimens; RM examined the specimens and identified the species morphologically; BP and SC prepared samples for genetic analysis; SC and RM conducted phylogenetic analysis; BP compiled the distribution maps; $\mathrm{BP}, \mathrm{SC}$ and $\mathrm{RB}$ drafted the manuscript; and all authors contributed edits.

Received: 19 May 2016

Accepted: 1 September 2016

Academic editor: Rodrigo B. Salvador

\section{APPENDIX}

Table A1. Distribution and presence data of Cipangopaludina japonica $(n=37)$ and Cipangopaludina chinensis $(n=505)$ gathered from United States Geological Survey Nonindigenous Aquatic Species Database (2016) and used to create distribution maps of collections reported in the United States (Figures 1 and 2). Records include localities within counties and states, year of record, HUC codes, drainage system and the state of introduction (unknown, collected or established).

\begin{tabular}{|c|c|c|c|c|c|c|c|}
\hline Id & State & County & Locality & Year & HUC \# & Drainage & Status \\
\hline \multicolumn{8}{|c|}{ Cipangopaludina japonica } \\
\hline 262117 & & & Lake Erie & 1940 & 4120200 & Lake Erie & collected \\
\hline 241133 & & & Lake Michigan & 1968 & 4060200 & Lake Michigan & established \\
\hline 157495 & $\mathrm{AL}$ & Mobile & Spring Hill Lake [just W of Mobile, AL] & 2003 & 3170008 & Escatawpa & collected \\
\hline 279560 & CA & Alameda & San Francisco Bay Area & 1892 & 18050004 & San Francisco Bay & established \\
\hline 551050 & $\mathrm{DE}$ & New Castle & Lums Pond, Lums Pond State Park & 2013 & 2040205 & Brandywine-Christina & unknown \\
\hline 157127 & $\mathrm{FL}$ & Orange & Lake Eola, in Orlando & 1994 & 3090101 & Kissimmee & collected \\
\hline 50186 & IN & & state non-specific & 1965 & 0 & & collected \\
\hline 627160 & KS & Ellsworth & Kanopolis seep stream & 2013 & 10260008 & Lower Smoky Hill & established \\
\hline 164560 & KS & Ottawa & Ottawa State Fishing Lake [ $8 \mathrm{mi} \mathrm{N}$ of Bennington] & 2005 & 10260015 & Solomon & established \\
\hline 242200 & KS & Ottawa & $\begin{array}{l}\text { Sand Creek } 1 / 2 \mathrm{mi} \text {. upstream from Ottawa State Fishing Lake } \\
\text { [just } \mathrm{S} \text { of Wells] }\end{array}$ & 2007 & 10260015 & Solomon & collected \\
\hline 238815 & KS & Ottawa & Solomon River [near Niles] & 2007 & 10260008 & Lower Smoky Hill & collected \\
\hline 52289 & MA & Middlesex & Concord River, Concord & 1965 & 1070005 & Concord & unknown \\
\hline 878001 & MD & Howard & Wilde Lake & 2015 & 2060006 & Patuxent & unknown \\
\hline 902609 & MD & Prince George's & $\begin{array}{l}\text { retaining pond along Hampshire Drive, adjacent to George } \\
\text { Washington Cemetery }\end{array}$ & 2014 & 2070010 & Middle Potomac-Anacostia-Occoquan & unknown \\
\hline 50185 & MI & & state non-specific & 1965 & 4000000 & Great Lakes Region & collected \\
\hline 52288 & MI & Jackson & Sparks [Foundation County] Park, Jackson, MI & 1965 & 4050004 & Upper Grand & unknown \\
\hline 253733 & MS & Tunica & $\begin{array}{l}\text { McKinney Bayou off Indian Mound Road (=Bud Perry Road and } \\
\text { Indian Creek Road), north of Hollywood }\end{array}$ & 2007 & 8030204 & Coldwater & collected \\
\hline 164627 & $\mathrm{NE}$ & Douglas & Hitchcock Park Lake in Omaha & 1999 & 10230006 & Big Papillion-Mosquito & collected \\
\hline 52698 & $\mathrm{NE}$ & Lancaster & Hedgefield Lake Reservoir [ 3 mi. SE of Hickman, NE] & 1998 & 10200203 & Salt & established \\
\hline
\end{tabular}


Table A1. Continued.

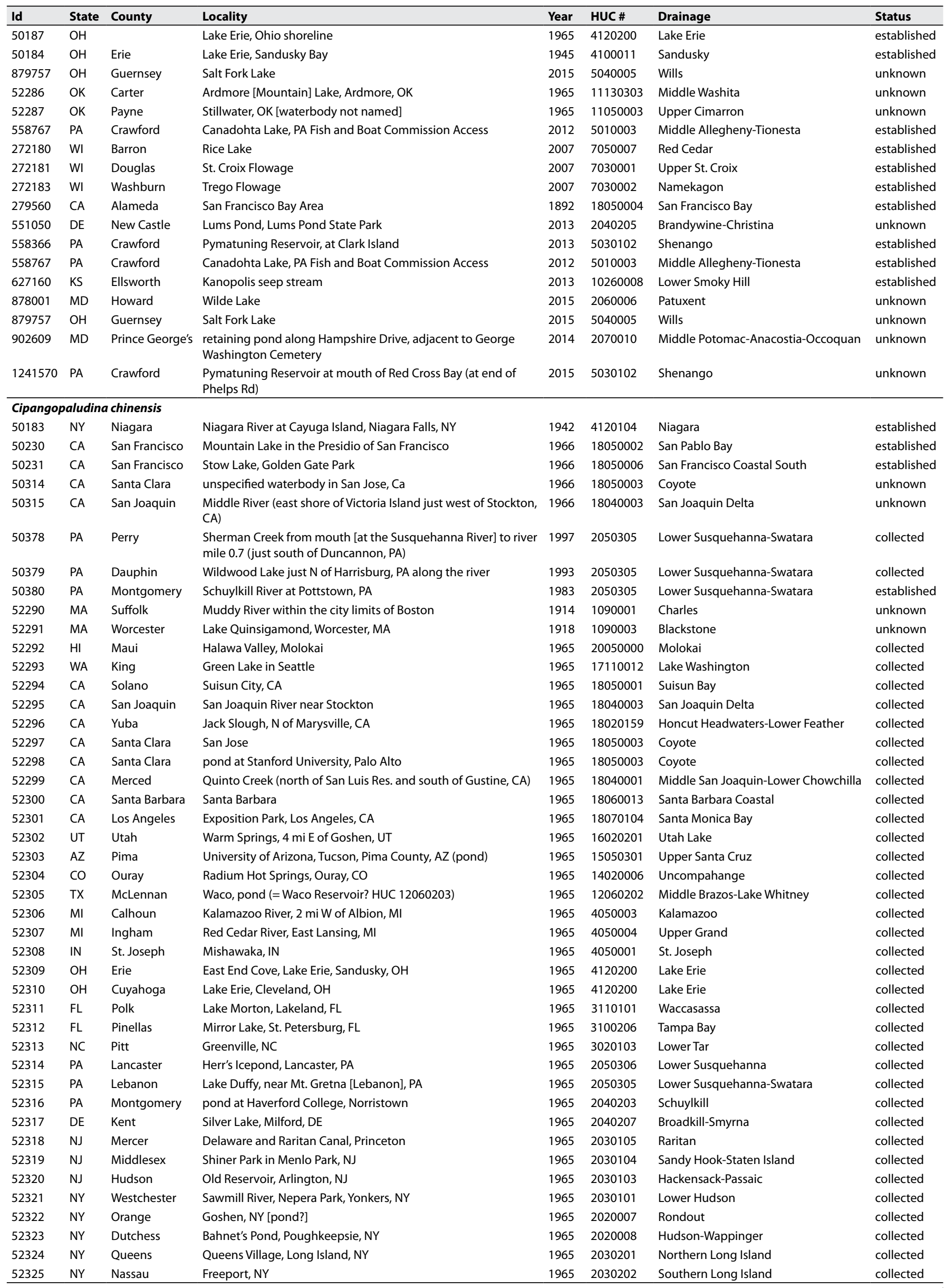


Table A1. Continued.

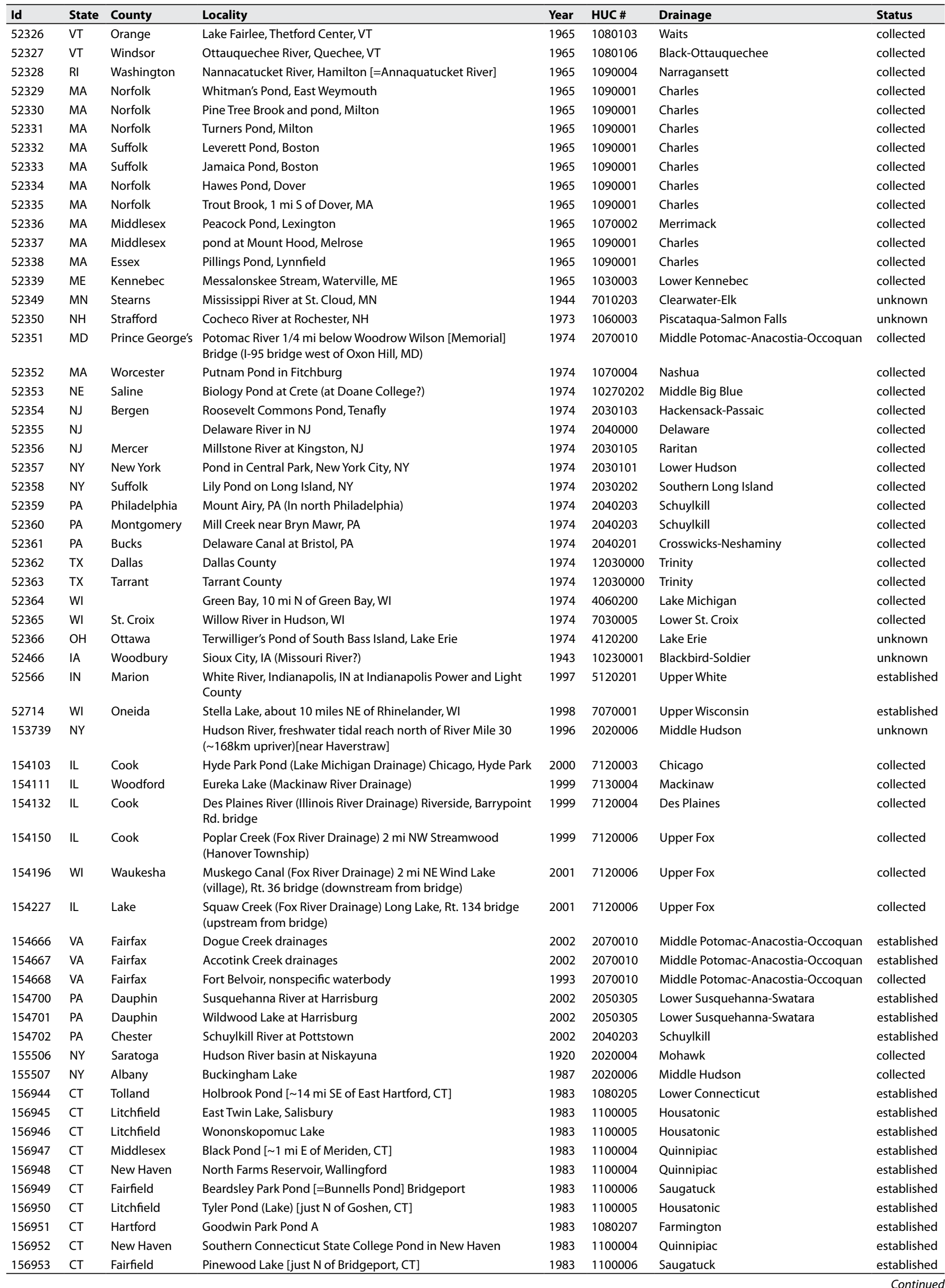


Table A1. Continued.

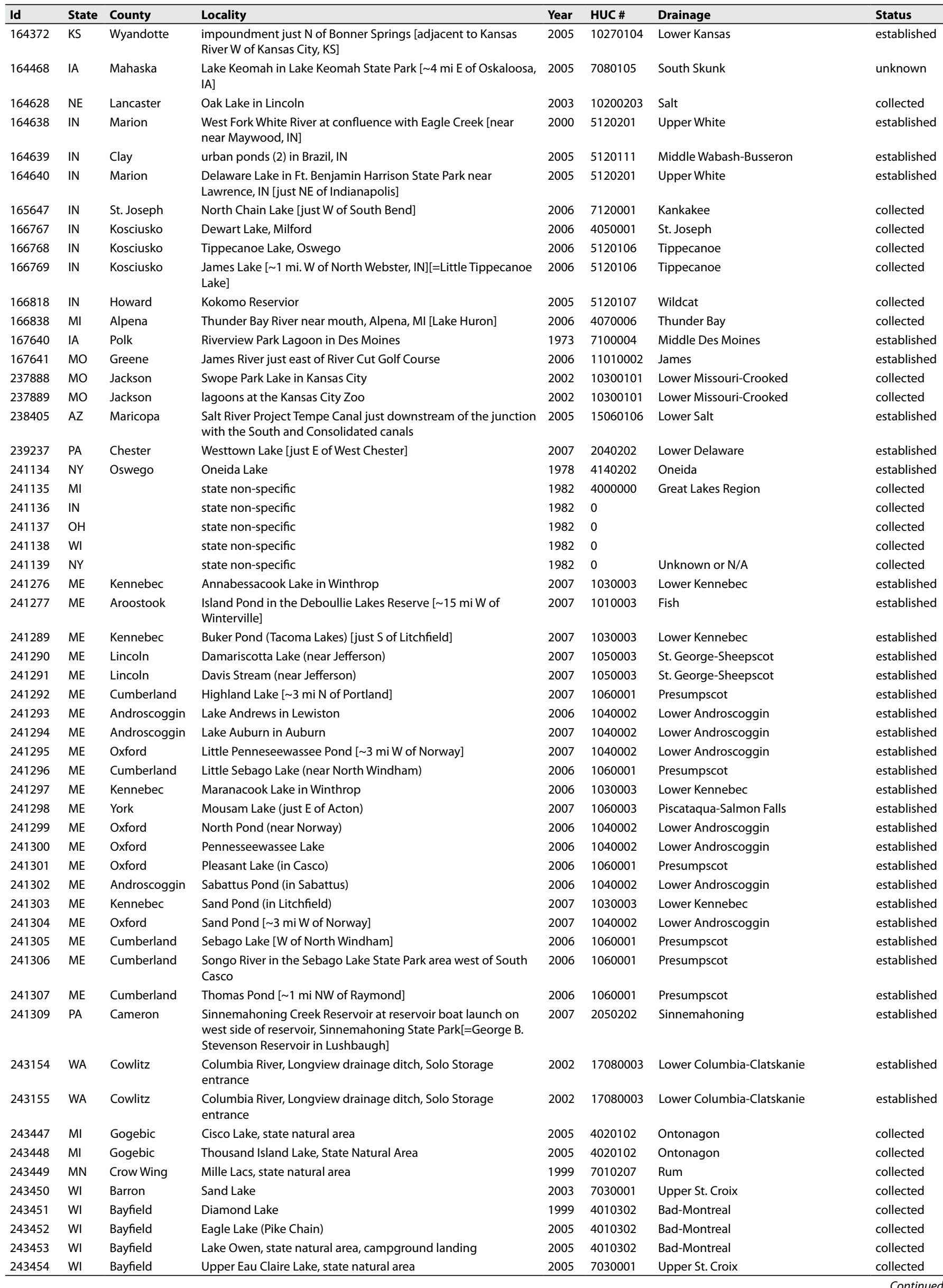


Table A1. Continued.

\begin{tabular}{|c|c|c|c|c|c|c|c|}
\hline Id & State & County & Locality & Year & HUC \# & Drainage & Status \\
\hline 243455 & WI & Burnett & Long Lake, state natural area & 1999 & 7030001 & Upper St. Croix & collected \\
\hline 243456 & WI & Burnett & McKenzie Lake, state natural area & 2003 & 7030002 & Namekagon & collected \\
\hline 243457 & WI & Douglas & Saint Croix Flowage, state natural area & 2005 & 7030001 & Upper St. Croix & collected \\
\hline 243458 & WI & Forest & Kentuck Lake & 1999 & 4030106 & Brule & collected \\
\hline 243459 & WI & lowa & Black Hawk Lake, state natural area & 1999 & 7070005 & Lower Wisconsin & collected \\
\hline 243460 & WI & Iron & Fisher Lake, state natural area & 1999 & 7050002 & Flambeau & collected \\
\hline 243461 & WI & Iron & Giles Flowage [a reservoir just S of Montreal, WI] & 1999 & 4010302 & Bad-Montreal & collected \\
\hline 243463 & WI & Iron & Weber Lake [just N of Upson] & 1999 & 4010302 & Bad-Montreal & collected \\
\hline 243464 & WI & Jefferson & Rock Lake & 2005 & 7090002 & Crawfish & collected \\
\hline 243465 & WI & Oneida & Bearskin Lake & 1999 & 7070001 & Upper Wisconsin & established \\
\hline 243466 & WI & Oneida & Buffalo Lake, state natural area & 2005 & 7070001 & Upper Wisconsin & established \\
\hline 243467 & WI & Oneida & Carrol Lake. State natural area. & 2005 & 7070001 & Upper Wisconsin & collected \\
\hline 243468 & WI & Oneida & Clear Lake, state natural area & 2005 & 7070001 & Upper Wisconsin & collected \\
\hline 243469 & WI & Oneida & Cunard Lake, state natural area & 2006 & 7070001 & Upper Wisconsin & collected \\
\hline 243471 & WI & Oneida & Little Tomahawk Lake & 2006 & 7070001 & Upper Wisconsin & collected \\
\hline 243472 & WI & Oneida & Madeline Lake. State natural area. & 2005 & 7070001 & Upper Wisconsin & collected \\
\hline 243473 & WI & Oneida & Mid Lake (a.k.a. Nawaii Lake) & 2006 & 7070001 & Upper Wisconsin & collected \\
\hline 243474 & WI & Lincoln & Lake Nokomis & 1999 & 7070001 & Upper Wisconsin & collected \\
\hline 243475 & WI & Oneida & Pelican Lake, Oneida County & 1999 & 7070001 & Upper Wisconsin & collected \\
\hline 243476 & WI & Oneida & Pickerel Lake. State natural area. & 2005 & 7070001 & Upper Wisconsin & collected \\
\hline 243477 & WI & Oneida & Rainbow Flowage (Wisconsin River in part) & 2006 & 7070001 & Upper Wisconsin & collected \\
\hline 243478 & WI & Oneida & Sand Lake & 2006 & 7070001 & Upper Wisconsin & collected \\
\hline 243479 & WI & Oneida & Squaw Lake & 1999 & 7050003 & South Fork Flambeau & collected \\
\hline 243480 & WI & Oneida & Squirrel Lake & 1999 & 7070001 & Upper Wisconsin & collected \\
\hline 243481 & WI & Oneida & Stone Lake & 2006 & 7070001 & Upper Wisconsin & collected \\
\hline 243482 & WI & Oneida & The Thoroughfare, state natural area & 1999 & 7070001 & Upper Wisconsin & collected \\
\hline 243483 & WI & Oneida & Tomahawk Lake & 2006 & 7070001 & Upper Wisconsin & collected \\
\hline 243484 & WI & Oneida & Willow Reservoir, state natural area. & 1999 & 7070001 & Upper Wisconsin & collected \\
\hline 243485 & WI & Oneida & Wisconsin River & 2005 & 7070001 & Upper Wisconsin & collected \\
\hline 243488 & WI & Polk & Wapogasset Lake, state natural area & 2003 & 7030005 & Lower St. Croix & collected \\
\hline 243489 & WI & Sawyer & Lake Chetac, state natural area & 2005 & 7050007 & Red Cedar & collected \\
\hline 243490 & WI & Sawyer & Lake Chippewa (Chippewa Flowage) & 1999 & 7050001 & Upper Chippewa & collected \\
\hline 243491 & WI & Sawyer & Lac Courte Oreilles, state natural area & 2005 & 7050001 & Upper Chippewa & collected \\
\hline 243492 & WI & Sawyer & Nelson Lake, state natural area & 2003 & 7030002 & Namekagon & established \\
\hline 243493 & WI & Sawyer & Sand Lake, state natural area & 1999 & 7050001 & Upper Chippewa & collected \\
\hline 243494 & WI & Vilas & Allequash Lake, state natural area & 1999 & 7050002 & Flambeau & collected \\
\hline 243495 & WI & Vilas & Big Lake & 2005 & 4020102 & Ontonagon & collected \\
\hline 243496 & WI & Vilas & Big Arbor Vitae Lake & 2005 & 7070001 & Upper Wisconsin & collected \\
\hline 243497 & WI & Vilas & Big Saint Germain Lake & 2005 & 7070001 & Upper Wisconsin & collected \\
\hline 243498 & WI & Vilas & Lake Content, state natural area & 2005 & 7070001 & Upper Wisconsin & collected \\
\hline 243499 & WI & Vilas & Lac du Lune, state natural area & 2006 & 4020102 & Ontonagon & collected \\
\hline 243500 & WI & Vilas & Lac Vieux Desert Lake & 1999 & 7070001 & Upper Wisconsin & collected \\
\hline 243501 & WI & Vilas & Little Arbor Vitae Lake & 2005 & 7070001 & Upper Wisconsin & collected \\
\hline 243502 & WI & Vilas & Little Gibson Lake, state natural area & 2005 & 7050002 & Flambeau & collected \\
\hline 243503 & WI & Vilas & Little Rice Lake, state natural area & 2006 & 7050002 & Flambeau & collected \\
\hline 243504 & WI & Vilas & Little Saint Germain. State natural area. & 2005 & 7070001 & Upper Wisconsin & collected \\
\hline 243505 & WI & Vilas & Lost Lake. State natural area. & 2005 & 7070001 & Upper Wisconsin & collected \\
\hline 243506 & WI & Vilas & Manitowish River, state natural area & 2005 & 7050002 & Flambeau & collected \\
\hline 243507 & WI & Vilas & Manitowish River, state natural area & 2006 & 7050002 & Flambeau & established \\
\hline 243508 & WI & Vilas & Moon Lake, state natural area & 2005 & 7070001 & Upper Wisconsin & collected \\
\hline 243509 & WI & Vilas & Plum Lakes & 2005 & 7070001 & Upper Wisconsin & collected \\
\hline 243510 & WI & Vilas & Razorback Lake & 2005 & 7070001 & Upper Wisconsin & collected \\
\hline 243511 & WI & Vilas & Round Lake & 2005 & 7050002 & Flambeau & collected \\
\hline 243512 & WI & Vilas & Snipe Lake, state natural area & 2005 & 7070001 & Upper Wisconsin & collected \\
\hline 243513 & WI & Vilas & Spring Creek, state natural area & 2006 & 7070001 & Upper Wisconsin & collected \\
\hline 243514 & WI & Vilas & Star Lake & 2005 & 7070001 & Upper Wisconsin & collected \\
\hline 243515 & WI & Vilas & Upper Gresham Lake, state natural area. & 2005 & 7050002 & Flambeau & collected \\
\hline 243516 & WI & Vilas & West Plum Lake, state natural area. & 2005 & 7070001 & Upper Wisconsin & collected \\
\hline 243517 & WI & Vilas & Wildcat Lake, state natural area & 2005 & 7050002 & Flambeau & collected \\
\hline
\end{tabular}


Table A1. Continued.

\begin{tabular}{|c|c|c|c|c|c|c|c|}
\hline Id & State & County & Locality & Year & HUC \# & Drainage & Status \\
\hline 243521 & WI & Washburn & Shell Lake, state natural area & 2003 & 7030001 & Upper St. Croix & collected \\
\hline 252825 & WI & Adams & Goose Lake & 2007 & 4030201 & Upper Fox & collected \\
\hline 252826 & WI & Adams & Wolf Lake & 2007 & 4030201 & Upper Fox & collected \\
\hline 252827 & WI & Ashland & Long Lake & 2007 & 4010302 & Bad-Montreal & collected \\
\hline 252828 & WI & Barron & Big Dummy Lake & 2007 & 7050007 & Red Cedar & collected \\
\hline 252830 & WI & Barron & Chetek Lake & 2007 & 7050007 & Red Cedar & collected \\
\hline 252831 & WI & Barron & Echo Lake & 2007 & 7030005 & Lower St. Croix & collected \\
\hline 252834 & WI & Barron & Little Dummy Lake & 2007 & 7050007 & Red Cedar & collected \\
\hline 252835 & WI & Barron & North Lake & 2007 & 7030005 & Lower St. Croix & collected \\
\hline 252836 & WI & Barron & Rice Lake & 2007 & 7050007 & Red Cedar & collected \\
\hline 252837 & WI & Barron & Scott Lake & 2007 & 7030005 & Lower St. Croix & collected \\
\hline 252838 & WI & Barron & Silver Lake, ner Cumberland, near CR B & 2007 & 7050007 & Red Cedar & collected \\
\hline 252839 & WI & Barron & Staples Lake & 2007 & 7030005 & Lower St. Croix & collected \\
\hline 252840 & WI & Bayfield & Delta Lake & 2008 & 4010302 & Bad-Montreal & collected \\
\hline 252843 & WI & Burnett & Devils Lake & 2007 & 7030001 & Upper St. Croix & collected \\
\hline 252845 & WI & Burnett & Gaslyn Lake & 2007 & 7030001 & Upper St. Croix & collected \\
\hline 252846 & WI & Burnett & Gull Lake & 1999 & 7030001 & Upper St. Croix & collected \\
\hline 252848 & WI & Burnett & Mud Hen Lake & 2007 & 7030005 & Lower St. Croix & collected \\
\hline 252849 & WI & Burnett & Twenty-Six Lake & 2007 & 7030001 & Upper St. Croix & collected \\
\hline 252850 & WI & Chippewa & Lake Wissota (Yellow River Basin) & 1999 & 7050005 & Lower Chippewa & collected \\
\hline 252851 & WI & Dane & Elver Park Pond & 2008 & 7070005 & Lower Wisconsin & collected \\
\hline 252852 & WI & Eau Claire & Fall Creek Pond & 1999 & 7050006 & Eau Claire & collected \\
\hline 252853 & WI & Eau Claire & Halfmoon Lake & 2008 & 7050005 & Lower Chippewa & collected \\
\hline 252854 & WI & Florence & Sea Lion Lake & 1999 & 4030108 & Menominee & collected \\
\hline 252855 & WI & Forest & Little Rice Lake & 1999 & 4030202 & Wolf & collected \\
\hline 252856 & WI & Forest & Pine Lake & 2007 & 4030202 & Wolf & collected \\
\hline 252857 & WI & Iron & Manitowish River & 2005 & 7050002 & Flambeau & collected \\
\hline 252858 & WI & Iron & O'Brien Lake & 2007 & 4010302 & Bad-Montreal & collected \\
\hline 252859 & WI & Lincoln & Nokomis Lake (Rice River Flowage) & 1999 & 7070001 & Upper Wisconsin & collected \\
\hline 252863 & WI & Oconto & Pickerel Lake & 1999 & 4030104 & Oconto & collected \\
\hline 252865 & WI & Oconto & Shay Lake & 2008 & 4030104 & Oconto & collected \\
\hline 253557 & MO & Laclede & $\begin{array}{l}\text { Niangua River [W of Prosperine] at Mountain Creek } \\
\text { Campgound canoe launch }\end{array}$ & 2008 & 10290110 & Niangua & collected \\
\hline 255088 & OR & Marion & $\begin{array}{l}\text { pond (old rock quarry and log pond) at } 3000 \text { Cherry Ave. in } \\
\text { Salem }\end{array}$ & 2008 & 17090007 & Middle Willamette & collected \\
\hline 255246 & MI & Alpena & $\begin{array}{l}\text { Lake Winyah, shore, boat channel and ponds in private } \\
\text { campground }\end{array}$ & 2008 & 4070006 & Thunder Bay & established \\
\hline 255850 & OR & Linn & $\begin{array}{l}\text { Cox Creek at Bain Drive [St.] SE in Albany (also known as Swan } \\
\text { Lakes) }\end{array}$ & 2008 & 17090003 & Upper Willamette & unknown \\
\hline 255970 & IN & Elkhart & Elkhart River, from Goshen to Dunlap & 2008 & 4050001 & St. Joseph & unknown \\
\hline 255972 & IN & Kosciusko & Kuhn Lake about 4 miles SW of North Webster, IN & 2006 & 5120106 & Tippecanoe & unknown \\
\hline 255975 & IN & Kosciusko & Oswego Lake [Oswego, IN] & 2006 & 5120106 & Tippecanoe & unknown \\
\hline 256702 & MO & Johnson & Lake Buteo, Knob Noster State Park in Knob Noster & 2008 & 10300104 & Blackwater & unknown \\
\hline 256703 & MO & Johnson & Powell Gardens Lake [ 1 mi NW of Elm] & 2008 & 10300104 & Blackwater & unknown \\
\hline 257040 & IN & Marion & $\begin{array}{l}\text { Fall Creek, vicinity of the Delaware Lake Dam (Ft. Harrison State } \\
\text { Park, in NE Indianapolis) }\end{array}$ & 2008 & 5120201 & Upper White & established \\
\hline 260618 & MO & Jackson & $\begin{array}{l}\text { Alex George Lake in the Blue River Parkway [near I-435 and } \\
\text { Blue River Rd. south side of Kansas City] }\end{array}$ & 2009 & 10300101 & Lower Missouri-Crooked & established \\
\hline 261734 & MO & Jackson & $\begin{array}{l}\text { Bowlin Road Pond in Blue Springs Park [=Fleming Park, just ESE } \\
\text { of Kansas City] }\end{array}$ & 2009 & 10300101 & Lower Missouri-Crooked & established \\
\hline 261982 & MO & Jackson & Lake Jacomo, near Kansas City & 2009 & 10300101 & Lower Missouri-Crooked & established \\
\hline 261983 & NY & Sullivan & Braden Brook, just N of Mountain Dale & 2009 & 2020007 & Rondout & established \\
\hline 262118 & NY & Niagara & Niagara River & 1931 & 4120104 & Niagara & collected \\
\hline 263832 & PA & Cumberland & Conodoguinet Creek, at mouth [Harrisburg] & 2002 & 2050305 & Lower Susquehanna-Swatara & established \\
\hline 264163 & MO & Randolph & $\begin{array}{l}\text { Rothwell Lake, just upstream of the Rothwell Park Road bridge } \\
\text { [in Moberly] }\end{array}$ & 2009 & 10280203 & Little Chariton & collected \\
\hline 264165 & MO & Jackson & $\begin{array}{l}\text { Penn Valley Park pond, near the intersection of Penn Valley } \\
\text { Drive and 27th Street, Kansas City }\end{array}$ & 2009 & 10270104 & Lower Kansas & established \\
\hline 264168 & NY & Putnam & $\begin{array}{l}\text { John Allen Pond in Clarence Fahnestock State Park in Putnam } \\
\text { Valley }\end{array}$ & 2009 & 2030101 & Lower Hudson & established \\
\hline 265065 & $\mathrm{FL}$ & Lee & a canal in Cape Coral & 2009 & 3100103 & Charlotte Harbor & established \\
\hline
\end{tabular}


Table A1. Continued.

\begin{tabular}{|c|c|c|c|c|c|c|c|}
\hline Id & State & County & Locality & Year & HUC \# & Drainage & Status \\
\hline 265684 & ONT & & $\begin{array}{l}\text { Stony Lake, Dummer Twp., Peterborough Co, near Mt. Eagle } \\
\text { Island }\end{array}$ & 1996 & & & collected \\
\hline 265685 & ONT & & $\begin{array}{l}\text { Stony Lake, Dummer Twp., Peterborough Co., Near Fairy Lake } \\
\text { Island. }\end{array}$ & 1996 & & & collected \\
\hline 268945 & IN & Hamilton & Fall Creek at Geist Reservoir (just NE of Indianapolis) & 2010 & 5120201 & Upper White & established \\
\hline 269215 & NY & Sullivan & Bashakill Marsh [S of Wurtsboro] & 2010 & 2040101 & Upper Delaware & established \\
\hline 269217 & NY & Sullivan & Silver Lake (Kreiger Park) in Woodridge & 2010 & 2020007 & Rondout & established \\
\hline 269468 & ID & Latah & Arboretum Pond on University of Idaho campus [Moscow] & 2008 & 17060108 & Palouse & established \\
\hline 269735 & OR & Klamath & $\begin{array}{l}\text { Lost River at Crystal Springs Road boat ramp [SE of Klamath } \\
\text { Falls] }\end{array}$ & 2010 & 18010204 & Lost & collected \\
\hline 270109 & WI & Vilas & Alder Lake & 2007 & 7050002 & Flambeau & established \\
\hline 270110 & WI & Eau Claire & Altoona Lake & 2009 & 7050006 & Eau Claire & established \\
\hline 270111 & WI & Rusk & Amacoy Lake & 2009 & 7050001 & Upper Chippewa & established \\
\hline 270112 & WI & Vilas & Anvil Lake & 2006 & 7070001 & Upper Wisconsin & established \\
\hline 270113 & WI & Adams & Arkdale Lake (Arkdale Millpond) & 2009 & 7070003 & Castle Rock & established \\
\hline 270116 & WI & Barron & Barron Flowage \#3 & 2009 & 7050007 & Red Cedar & established \\
\hline 270119 & WI & Lincoln & Bass Lake & 2008 & 7070001 & Upper Wisconsin & established \\
\hline 270121 & WI & Rusk & Bass Lake & 2009 & 7050001 & Upper Chippewa & established \\
\hline 270122 & WI & Washburn & Bass Lake & 2007 & 7050007 & Red Cedar & established \\
\hline 270128 & WI & Barron & Bear Lake & 2009 & 7050007 & Red Cedar & established \\
\hline 270130 & WI & Washburn & Bear Lake & 2009 & 7050007 & Red Cedar & established \\
\hline 270131 & WI & Portage & Bear Lake & 2008 & 4030202 & Wolf & established \\
\hline 270132 & WI & Portage & Bear Lake & 2008 & 4030202 & Wolf & established \\
\hline 270133 & WI & Vilas & Big Bass Lake & 2006 & 7070001 & Upper Wisconsin & established \\
\hline 270134 & WI & Washburn & Big Bass Lake & 2007 & 7030002 & Namekagon & established \\
\hline 270136 & WI & Polk & Big Blake Lake (Blake) & 2007 & 7030005 & Lower St. Croix & established \\
\hline 270137 & WI & Oneida & Big Fork Lake & 2007 & 7070001 & Upper Wisconsin & established \\
\hline 270138 & WI & Burnett & Big McKenzie Lake & 2005 & 7030001 & Upper St. Croix & established \\
\hline 270139 & WI & Washburn & Big McKenzie Lake & 2005 & 7030002 & Namekagon & established \\
\hline 270140 & WI & Barron & Big Moon Lake & 2009 & 7050007 & Red Cedar & established \\
\hline 270143 & WI & Langlade & Big Twin Lake & 2009 & 4030202 & Wolf & established \\
\hline 270145 & WI & Washburn & Birch Lake & 2008 & 7050007 & Red Cedar & established \\
\hline 270146 & WI & Sawyer & Birch Lake & 2008 & 7050007 & Red Cedar & established \\
\hline 270147 & WI & Polk & Bone Lake & 2007 & 7030005 & Lower St. Croix & established \\
\hline 270148 & WI & Oneida & Booth Lake & 2007 & 7070001 & Upper Wisconsin & established \\
\hline 270149 & WI & Vilas & Boulder Lake & 2006 & 7050002 & Flambeau & established \\
\hline 270150 & WI & Vilas & Brandy Lake & 2006 & 7070001 & Upper Wisconsin & established \\
\hline 270151 & WI & Oneida & Buckskin Lake & 2007 & 7050003 & South Fork Flambeau & established \\
\hline 270152 & WI & Vilas & Buckskin Lake & 2007 & 7050003 & South Fork Flambeau & established \\
\hline 270154 & WI & Price & Butternut Lake & 2008 & 7050002 & Flambeau & established \\
\hline 270155 & WI & Ashland & Butternut Lake & 2008 & 7050002 & Flambeau & established \\
\hline 270156 & WI & Ashland & Butternut Lake & 2008 & 7050002 & Flambeau & established \\
\hline 270162 & WI & Washburn & Cable Lake & 2007 & 7030001 & Upper St. Croix & established \\
\hline 270163 & WI & Polk & Camelia Lake & 2007 & 7030005 & Lower St. Croix & established \\
\hline 270164 & WI & Vilas & Carpenter Lake & 2010 & 7070001 & Upper Wisconsin & established \\
\hline 270165 & WI & Vilas & Catfish Lake & 2010 & 7070001 & Upper Wisconsin & established \\
\hline 270167 & WI & Chippewa & Chapman Lake & 2009 & 7050006 & Eau Claire & established \\
\hline 270168 & WI & Taylor & Chequamegon Waters Flowage & 2010 & 7050005 & Lower Chippewa & established \\
\hline 270169 & WI & Oconto & Chute Pond & 2008 & 4030104 & Oconto & established \\
\hline 270170 & WI & Polk & Clam Falls Flowage & 2007 & 7030001 & Upper St. Croix & established \\
\hline 270171 & WI & Polk & Clear Lake & 2007 & 7030005 & Lower St. Croix & established \\
\hline 270172 & WI & Portage & Collins Lake & 2008 & 4030202 & Wolf & established \\
\hline 270299 & WI & Eau Claire & Coon Fork Lake & 2009 & 7050006 & Eau Claire & established \\
\hline 270325 & WI & lowa & Cox Hollow Lake & 2007 & 7070005 & Lower Wisconsin & unknown \\
\hline 270326 & WI & Vilas & Cranberry Lake & 2010 & 7070001 & Upper Wisconsin & unknown \\
\hline 270327 & WI & Oneida & Cranberry Lake (Eagle Chain) & 2010 & 4140202 & Oneida & unknown \\
\hline 270328 & WI & Oneida & Deer Lake & 2007 & 7070001 & Upper Wisconsin & unknown \\
\hline 270329 & WI & lowa & Cox Hollow Lake & 2007 & 7070005 & Lower Wisconsin & unknown \\
\hline 270330 & WI & Bayfield & Delta Lake & 2010 & 4010302 & Bad-Montreal & unknown \\
\hline 270331 & WI & Sauk & Devils Lake (Spirit Lake) & 2008 & 7070004 & Baraboo & unknown \\
\hline
\end{tabular}


Table A1. Continued.

\begin{tabular}{|c|c|c|c|c|c|c|c|}
\hline Id & State & County & Locality & Year & HUC \# & Drainage & Status \\
\hline 270336 & WI & Florence & Emily Lake & 2009 & 4030108 & Menominee & unknown \\
\hline 270337 & WI & Langlade & Enterprise Lake & 2008 & 4030202 & Wolf & unknown \\
\hline 270338 & WI & Florence & Fay Lake & 2009 & 4030108 & Menominee & unknown \\
\hline 270339 & WI & Washburn & Fenton Lake & 2006 & 7050007 & Red Cedar & unknown \\
\hline 270340 & WI & Rusk & Fireside Lakes & 2009 & 7050001 & Upper Chippewa & unknown \\
\hline 270341 & WI & Rusk & Flambeau River & 2010 & 7050001 & Upper Chippewa & unknown \\
\hline 270342 & WI & Rusk & Flambeau River & 2010 & 7050001 & Upper Chippewa & unknown \\
\hline 270344 & WI & Oconto & Grindle Lake & 2008 & 4030104 & Oconto & unknown \\
\hline 270346 & WI & Vilas & Gunlock Lake & 2007 & 7070001 & Upper Wisconsin & unknown \\
\hline 270347 & WI & Sawyer & Hayward Lake & 2010 & 7030002 & Namekagon & unknown \\
\hline 270349 & WI & Vilas & High Lake & 2006 & 7050002 & Flambeau & unknown \\
\hline 270351 & WI & Chippewa & Holcombe Flowage & 2008 & 7050001 & Upper Chippewa & unknown \\
\hline 270353 & WI & Oneida & Horsehead Lake (Leta) & 2007 & 7070001 & Upper Wisconsin & unknown \\
\hline 270355 & WI & Barron & Horseshoe Lake & 2007 & 7030001 & Upper St. Croix & unknown \\
\hline 270364 & WI & Price & Hultman Lake & 2009 & 7070001 & Upper Wisconsin & unknown \\
\hline 270365 & WI & Oneida & Hat Rapids Flowage & 2007 & 7070001 & Upper Wisconsin & unknown \\
\hline 270366 & WI & Barron & Hemlock Lake & 2009 & 7050007 & Red Cedar & unknown \\
\hline 270368 & WI & Vilas & Hunter Lake & 2008 & 7070001 & Upper Wisconsin & unknown \\
\hline 270369 & WI & Oneida & Jennie Webber Lake & 2007 & 7070001 & Upper Wisconsin & unknown \\
\hline 270370 & WI & Portage & Joanis Lake & 2008 & 7070003 & Castle Rock & unknown \\
\hline 270371 & WI & Florence & Keyes Lake & 2009 & 4030108 & Menominee & unknown \\
\hline 270372 & WI & Price & Lac Sault Dore & 2008 & 7050003 & South Fork Flambeau & unknown \\
\hline 270374 & WI & Barron & Lake Desair & 2009 & 7050007 & Red Cedar & unknown \\
\hline 270375 & WI & Wood & Lake Dexter & 2009 & 7070003 & Castle Rock & unknown \\
\hline 270376 & WI & Marathon & Lake Dubay (T26N, R6E,S14) & 2001 & 7070002 & Lake Dubay & unknown \\
\hline 270377 & WI & Portage & Lake Dubay & 2001 & 7070003 & Castle Rock & unknown \\
\hline 270378 & WI & Oneida & Lake Minocqua & 2006 & 7070001 & Upper Wisconsin & unknown \\
\hline 270379 & WI & Oneida & Lake Thompson & 2008 & 7070001 & Upper Wisconsin & unknown \\
\hline 270381 & WI & Sawyer & Lake of the Pines & 2008 & 7050002 & Flambeau & unknown \\
\hline 270384 & WI & Portage & Lime Lake & 2008 & 7070003 & Castle Rock & unknown \\
\hline 270386 & WI & Washburn & Lincoln Lake & 2007 & 7030002 & Namekagon & unknown \\
\hline 270390 & WI & Washburn & Little Bass Lake & 2007 & 7030002 & Namekagon & unknown \\
\hline 270392 & WI & Oneida & Little Bearskin Lake & 2006 & 7070001 & Upper Wisconsin & unknown \\
\hline 270393 & WI & Ashland & Little Butternut Lake & 2008 & 7050002 & Flambeau & unknown \\
\hline 270444 & WI & Oneida & Little Fork Lake & 2007 & 7070001 & Upper Wisconsin & unknown \\
\hline 270445 & WI & Vilas & Little John Lake & 2010 & 7050002 & Flambeau & unknown \\
\hline 270446 & WI & Vilas & Little Spider Lake (a.k.a. Gaffrey Lake) & 2006 & 7070001 & Upper Wisconsin & unknown \\
\hline 270447 & WI & Florence & Long Lake & 2009 & 4030108 & Menominee & unknown \\
\hline 270448 & WI & Florence & Long Lake & 2009 & 4030108 & Menominee & unknown \\
\hline 270449 & WI & Vilas & Long Lake & 2007 & 7070001 & Upper Wisconsin & unknown \\
\hline 270450 & WI & Barron & Loon Lake, west of Constock, on the Barron/Polk County border & 2009 & 7030005 & Lower St. Croix & unknown \\
\hline 270451 & WI & Shawano & Loon Lake & 2009 & 4030202 & Wolf & unknown \\
\hline 270452 & WI & Shawano & Lower Red Lake (Weed Dam Pond) & 2010 & 4030202 & Wolf & unknown \\
\hline 270453 & WI & Barron & Lower Vermillion Lake & 2009 & 7050007 & Red Cedar & unknown \\
\hline 270454 & WI & Vilas & Lynx Lake (Eagle Chain) & 2007 & 7070001 & Upper Wisconsin & unknown \\
\hline 270455 & WI & Polk & Magnor Lake & 2007 & 7030005 & Lower St. Croix & unknown \\
\hline 270520 & MO & Jackson & $\begin{array}{l}\text { Lake Lotawana, (West Fork Sni-A-Bar Creek) at marina boat } \\
\text { ramp }\end{array}$ & 2010 & 10300101 & Lower Missouri-Crooked & established \\
\hline 271128 & IN & Vigo & Green Valley Mine Pond [NW of Terre Haute] & 2010 & 5120111 & Middle Wabash-Busseron & established \\
\hline 271137 & ID & Latah & Moose Creek Reservoir [NW of Bovill] & 2009 & 17060306 & Clearwater & collected \\
\hline 271138 & ID & Latah & Spring Valley Reservoir & 2010 & 17060306 & Clearwater & collected \\
\hline 272631 & OR & Jackson & $\begin{array}{l}\text { ponds ( } 2 \text { ) at Jackson County Sports Park off Kershaw Rd. in } \\
\text { White City }\end{array}$ & 2010 & 17100308 & Middle Rogue & established \\
\hline 272814 & WA & Thurston & Long Lake, west side at WDFW boat ramp. & 2010 & 17110019 & Puget Sound & established \\
\hline 272815 & WA & Thurston & Hicks Lake, north side of Washington State boat ramp. & 2010 & 17110019 & Puget Sound & established \\
\hline 272816 & WA & Thurston & Hicks Lake, south of Washington State boat ramp. & 2010 & 17110019 & Puget Sound & established \\
\hline 272817 & WA & Thurston & Chambers Lake, at Thurston County boat ramp. & 2010 & 17110016 & Deschutes & established \\
\hline 272818 & WA & Thurston & $\begin{array}{l}\text { Ken Lake (Simmons Lake) at Christopher Park off Cedarbury } \\
\text { Lane, Lakemoor Community Club. }\end{array}$ & 2010 & 17100103 & Upper Chehalis & established \\
\hline 272819 & WA & Thurston & $\begin{array}{l}\text { Ken Lake (Simmons Lake) at Westside Park off Camelot Park SW, } \\
\text { Lakemoor Community Club. }\end{array}$ & 2010 & 17100103 & Upper Chehalis & established \\
\hline
\end{tabular}


Table A1. Continued.

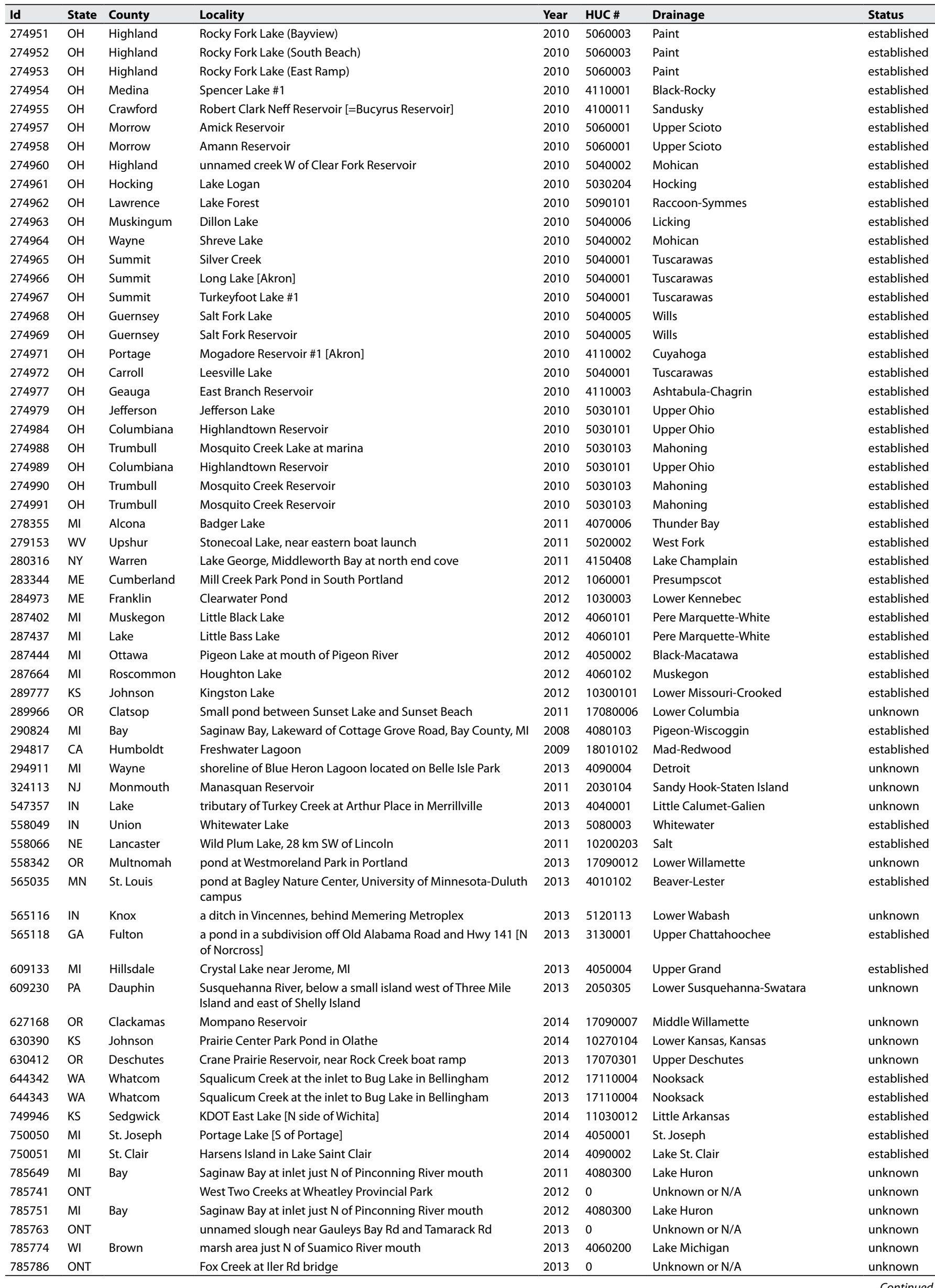


Table A1. Continued.

\begin{tabular}{|c|c|c|c|c|c|c|c|}
\hline Id & State & County & Locality & Year & HUC \# & Drainage & Status \\
\hline 785798 & MI & Bay & Saginaw Bay at inlet just $\mathrm{N}$ of Pinconning River mouth & 2013 & 4080300 & Lake Huron & unknown \\
\hline 785810 & ONT & & Lake St Claire near shore at end of Mallard Line & 2012 & 4090002 & Lake St. Clair & unknown \\
\hline 785822 & $\mathrm{Ml}$ & Houghton & Silver Creek $\mathrm{N}$ of Kuusisto $\mathrm{Rd}$ & 2011 & 4020300 & Lake Superior & unknown \\
\hline 851575 & OR & Lane & Eugene East & 2013 & 17090002 & Coast Fork Willamette & established \\
\hline 851576 & OR & Clatsop & Gearhart & 2011 & 17100201 & Necanicum & established \\
\hline 862379 & WA & King & Pine Lake & 2015 & 17110012 & Lake Washington & established \\
\hline 862470 & VA & Fairfax & Mason Neck State Park & 2015 & 2070010 & Middle Potomac-Anacostia-Occoquan & established \\
\hline 862472 & VA & Fairfax & Mason Neck State Park & 2015 & 2070010 & Middle Potomac-Anacostia-Occoquan & established \\
\hline 862473 & VA & Fairfax & Mason Neck State Park & 2015 & 2070010 & Middle Potomac-Anacostia-Occoquan & established \\
\hline 862474 & VA & Fairfax & Pohick Bay & 2015 & 2070010 & Middle Potomac-Anacostia-Occoquan & established \\
\hline 862475 & VA & Fairfax & Dyke Marsh & 2015 & 2070010 & Middle Potomac-Anacostia-Occoquan & established \\
\hline 862476 & VA & Fairfax & Dyke Marsh & 2015 & 2070010 & Middle Potomac-Anacostia-Occoquan & established \\
\hline 862477 & VA & Fairfax & Dyke Marsh & 2015 & 2070010 & Middle Potomac-Anacostia-Occoquan & established \\
\hline 862478 & VA & Fairfax & Mason Neck State Park & 2015 & 2070010 & Middle Potomac-Anacostia-Occoquan & established \\
\hline 862480 & VA & Fairfax & Mason Neck State Park & 2015 & 2070010 & Middle Potomac-Anacostia-Occoquan & established \\
\hline 862481 & VA & Fairfax & Occoquan Regional Park & 2015 & 2070010 & Middle Potomac-Anacostia-Occoquan & established \\
\hline 862482 & VA & Fairfax & Occoquan Regional Park & 2015 & 2070010 & Middle Potomac-Anacostia-Occoquan & established \\
\hline 862483 & VA & Fairfax & Belle Haven Park & 2015 & 2070010 & Middle Potomac-Anacostia-Occoquan & established \\
\hline 862484 & VA & Fairfax & Pohick Bay & 2015 & 2070010 & Middle Potomac-Anacostia-Occoquan & established \\
\hline 862485 & VA & Fairfax & Occoquan Regional Park & 2015 & 2070010 & Middle Potomac-Anacostia-Occoquan & established \\
\hline 862486 & VA & Fairfax & Occoquan Regional Park & 2015 & 2070010 & Middle Potomac-Anacostia-Occoquan & established \\
\hline 862487 & VA & Prince William & Occoquan Regional Park & 2015 & 2070010 & Middle Potomac-Anacostia-Occoquan & established \\
\hline 862488 & VA & Fairfax & Occoquan Regional Park & 2015 & 2070010 & Middle Potomac-Anacostia-Occoquan & established \\
\hline 862489 & VA & Fairfax & Occoquan Regional Park & 2015 & 2070010 & Middle Potomac-Anacostia-Occoquan & established \\
\hline 877596 & $\mathrm{IL}$ & Kankakee & Kankakee River in Kankakee & 2015 & 7120001 & Kankakee & established \\
\hline 877645 & MA & Plymouth & $\begin{array}{l}\text { Great Herring Pond, at Sagamore Beach access off Eagle Hill } \\
\text { Drive }\end{array}$ & 2015 & 1090002 & Cape Cod & established \\
\hline 877664 & WV & Hardy & Rock Cliff lake at US Forest Service Trout Pond Campground & 2012 & 2070003 & Cacapon-Town & established \\
\hline 878070 & MI & Kalamazoo & Woods Lake, at dock at the Kensington Park entrance & 2015 & 4050003 & Kalamazoo & established \\
\hline
\end{tabular}

Table A2. Reports from state departments of natural resources (DNRs) about Cipangopaludina japonica used to add a layer (Figure 1) to the distribution map highlighting collections reported to the national United States Geological Survey Nonindigenous Aquatic Species Database (2016). Designation of $\mathrm{np}$ means information was not present.

\begin{tabular}{|c|c|c|c|c|c|}
\hline State & Postal code & Present & Status & Specific notes & Source \\
\hline Alabama & $\mathrm{AL}$ & yes & collected & & USGS 2016 \\
\hline Alaska & AK & no & $\mathrm{np}$ & & \\
\hline Arizona & $A Z$ & no & $\mathrm{np}$ & & \\
\hline Arkansas & $\mathrm{AR}$ & no & $\mathrm{np}$ & & \\
\hline California & CA & yes & established & & USGS 2016 \\
\hline Colorado & $\mathrm{CO}$ & no & $\mathrm{np}$ & & \\
\hline Connecticut & $\mathrm{CT}$ & no & $\mathrm{np}$ & & \\
\hline Delaware & $\mathrm{DE}$ & yes & unknown & & USGS 2016 \\
\hline Florida & $\mathrm{FL}$ & yes & collected & & USGS 2016 \\
\hline Georgia & GA & no & $\mathrm{np}$ & & \\
\hline Hawaii & $\mathrm{HI}$ & no & $\mathrm{np}$ & & \\
\hline Idaho & ID & yes & established & Invasive & http://www.agri.idaho.gov/AGRI/Categories/Environment/InvasiveSpeciesCouncil/InvSppList.php \\
\hline Illinois & IL & no & $\mathrm{np}$ & & \\
\hline Indiana & IN & yes & collected & & USGS 2016 \\
\hline lowa & IA & no & $\mathrm{np}$ & & \\
\hline Kansas & KS & yes & established & & USGS 2016 \\
\hline Kentucky & KY & no & $\mathrm{np}$ & & \\
\hline Louisiana & LA & no & $\mathrm{np}$ & & \\
\hline Maine & ME & no & $\mathrm{np}$ & & \\
\hline Maryland & MD & yes & unknown & & USGS 2016 \\
\hline Massachusetts & MA & yes & unknown & & USGS 2016 \\
\hline Michigan & MI & yes & collected & & USGS 2016 \\
\hline Minnesota & $\mathrm{MN}$ & yes & unknown & Regulated & http://www.midwesterngovernors.org/AIS/MGAStateBannedAquaticSpecies \\
\hline Mississippi & MS & yes & established & & USGS 2016 \\
\hline Missouri & MO & no & $\mathrm{np}$ & & \\
\hline Montana & MT & no & $\mathrm{np}$ & & \\
\hline Nebraska & NE & yes & established & & USGS 2016 \\
\hline
\end{tabular}


Table A2. Continued.

\begin{tabular}{|c|c|c|c|c|c|}
\hline State & Postal code & Present & Status & Specific notes & Source \\
\hline Nevada & NV & no & $\mathrm{np}$ & & \\
\hline New Hampshire & $\mathrm{NH}$ & no & $\mathrm{np}$ & & \\
\hline New Jersey & NJ & no & $\mathrm{np}$ & & \\
\hline New Mexico & NM & no & $\mathrm{np}$ & & \\
\hline New York & NY & yes & established & Widespread & http://www.nyis.info/user_uploads/601b9_Bellamya\%20japonica\%20Ecological.pdf \\
\hline North Carolina & NC & yes & established & Invasive & \\
\hline North Dakota & ND & no & $\mathrm{np}$ & & \\
\hline Oklahoma & OK & yes & unknown & & USGS 2016 \\
\hline Oregon & OR & yes & established & Invasive & http://www.dfw.state.or.us/conservationstrategy/invasive_species/mystery_snail.asp \\
\hline Pennsylvania & PA & yes & established & & USGS 2016 \\
\hline Rhode Island & $\mathrm{RI}$ & no & $\mathrm{np}$ & & \\
\hline South Carolina & SC & yes & established & Widespread & http://www.fwgna.org/sp_accts/B-japonica.pdf \\
\hline South Dakota & SD & no & $\mathrm{np}$ & & \\
\hline Tennessee & $\mathrm{TN}$ & no & $\mathrm{np}$ & & \\
\hline Utah & UT & no & $\mathrm{np}$ & & \\
\hline Vermont & VT & no & $\mathrm{np}$ & & \\
\hline Virginia & VA & yes & unknown & & http://www.fwgna.org/sp_accts/B-japonica.pdf \\
\hline Washington & WA & yes & established & & https://www.fws.gov/alaska/fisheries/fish/Technical_Reports/t_2010_107.pdf \\
\hline West Virginia & WV & no & $\mathrm{np}$ & & \\
\hline Wisconsin & WI & yes & established & & USGS 2016 \\
\hline Wyoming & WY & no & $\mathrm{np}$ & & \\
\hline
\end{tabular}

Table A3. Species, GenBank accession number, and references used to create the maximum likelihood phylogeny $(n=51)$.

\begin{tabular}{|c|c|c|}
\hline Species & GenBank Accession No. & Citation \\
\hline Cipangopaludina chinensis (Gray, 1834) & EU528474 & Hayes et al. 2008 \\
\hline Cipangopaludina chinensis (Gray, 1834) & EU528589 & Hayes et al. 2008 \\
\hline Cipangopaludina japonica (von Martens, 1861) & FJ405876 & Sengupta et al. 2009 \\
\hline Cipangopaludina chinensis (Gray, 1834) & FJ710298 & Hayes et al. 2009 \\
\hline Cipangopaludina dianchiensis Zhang, 1990 & GU198781 - GU198782 & Du et al. 2013 \\
\hline Cipangopaludina sp. & GU198783 - GU198784 & Du et al. 2013 \\
\hline Cipangopaludina dianchiensis Zhang, 1990 & GU198785 & Du et al. 2013 \\
\hline Cipangopaludina sp. & GU198786 - GU198791 & Du et al. 2013 \\
\hline Cipangopaludina longispira (Heude, 1890) & GU198809 - GU198810 & Du et al. 2013 \\
\hline Cipangopaludina dianchiensis Zhang, 1990 & GU198818 & Du et al. 2013 \\
\hline Cipangopaludina sp. & GU198819 & Du et al. 2013 \\
\hline Cipangopaludina dianchiensis Zhang, 1990 & JN621284 & Jiao et al. unpublished \\
\hline Cipangopaludina sp. & KP009560 & Tian et al. unpublished \\
\hline Cipangopaludina sp. & KP009566 & Tian et al. unpublished \\
\hline Cipangopaludina japonica (von Martens, 1861) & LC028524 - LC028535 & Hirano et al. 2015 \\
\hline Cipangopaludina chinensis laeta von Martens, 1860 & LC028536 - LC028548 & Hirano et al. 2015 \\
\hline Viviparus georgianus (I. Lea, 1834) & AF120634 & Giribet and Wheeler 2002 \\
\hline Viviparus contectus (Millet, 1813) & FJ405835 & Sengupta et al. 2009 \\
\hline Viviparus ater (de Cristofori \& Jan, 1832) & FJ405882 & Sengupta et al. 2009 \\
\hline
\end{tabular}

